\title{
Modern Algı Teorisinin Teolojik Kökenleri: Özgür İrade ve Determinizm Problemi
}

DOI NO: 10.5578/JSS.7215

Devrim Özkan ${ }^{1}$

\section{Özet}

Yirminci yüzyılın başından itibaren, insanın dış dünyayı nasıl anladiğı ve algıladı̆̆ sosyal bilimlerin başlıca meselelerinden biri olmuştur. Dış dünyada insandan bağımsız, kendi başına bir gerçekliğin var olduğundan giderek vazgeçilmesiyle birlikte, insanın gerçekliğin inşacısına dönüştüğü modernlik koşullarında, 'gerçekliğin insanlar arasındaki uzlaşmanın bir sonucu olduğu' giderek yaygın bir tartışma konusu haline gelmiştir. Buna paralel olarak, felsefe ve sosyal bilimler alanında, insanın dış dünyayı nasıl algıladığına yönelik problemler ile giderek daha fazla ilgilenilmeye başlanmıştır. Bu sayede, algı teorilerine ilginin giderek artmasıly birlikte, nesneyi farklı açllardan algılayan öznenin konumu, işlevi ve etkinliğinin biçimi daha önemli bir mesele haline gelmiştir. İnsanın gerçekliğe ulaşmak için nasıl bir metot kullanması gerektiği probleminden, insanın gerçekliği kendi konumuna göre nasıl farklı tarzlarda alglladığı problemine geçişse, çeşitli sosyal ve düşünsel gelişmelerin bir sonucudur. Nominalizmin Kuzey Avrupa'da etkin ve belirleyici bir düşünce akımı haline gelerek, önce tüm Avrupa'ya, daha sonra ise tüm dünyaya yayılması, sürecin belirleyici faktörüdür. Önceleri Luther ile Erasmus daha sonra ise Descartes ile Hobbes arasinda gerçekleşen 'özgür irade ve determinizm problemi'ne dair tartışmalarda, modern öznenin her şeyin merkezinde konumlandırllmasıyla, 'özgür iradeci' yaklaşımın yaygınlık kazanması algı teorilerine yönelik ilginin artmasını sağlayan başlıca etkendir. Bu nedenle günümüzde, özellikle sosyal psikoloji ve iletişim bilimlerinde yaygın biçimde başvurulan algı teorilerinin teolojik kökenleri, düşünce tarihi çalışmaları çerçevesinde, dikkatle ele alınmalıdır. Bu sayede, teolojik çalışmalar ile sosyal bilimler arasındaki bağlar ortaya çıkarllarak, algı teorisinden faydalanan kimi bilim sahalarının, kullandıkları metotların düşünsel kökenlerine dair farkındalık elde etmeleri temin edilebilir. Ayrıca, özellikle, iletişim bilimlerinde kullanılan çeşitli metotlarının biçimlenmesinde etkili olan algı teorilerinin teolojik kökenlerinin incelenmesi zaruridir. Zira insanın dış dünyayı nasıl bir biçimde algıladı̆̆ına dair incelemeler iletişim sistemlerinin inşasında etkili olmaktadır.

Anahtar Kelimeler: Algl Teorisi, Özgür Irade, Determinizm, Nominalizm, Aristotelesçilik

1 Yrd. Doç. Dr., İzmir Katip Çelebi Üniversitesi, Sosyal ve Beşeri Bilimler Fakültesi, Medya ve İletişim Bölümü. ozkandev@hotmail.com 


\title{
Theological Origins of Modern Perception Theory: The Problem of Free Will and Determinism
}

\begin{abstract}
Since the beginning of 20th century, how people understand and perceive external world has become a perennial concern of social sciences. The existence of a solitary reality apart from human stance was relinquished. By following this idea, it became a common discussion topic that 'reality is the result of a convention among people' in the modern conditions which people become builders of each reality. In parallel with this idea, the problems regarding how people perceive external world in philosophy and social sciences have become more significant. Therefore, the position, function and facility of the subject which perceive the other objects from different viewpoints became a more significant issue with the increasing interest in perception theories. To reach the reality, the transition from the problem of which methods people should follow to the problem of how people perceive reality based on their position is the outcome of various social and intellectual developments. Nominalism dominated Northern Europe and became determinative. Then, it expanded, first, to Europe and, then, to the world. In the discussions of 'free will and determinism' between, first, Luther and Erasmus, and then, between Descartes and Hobbes, there are two major components increasing the interest toward perception theories that they positioned the modern subject in the center of everything, and free will became widespread. In this sense, theological roots of perception theories which appeal particularly to social psychology and communication sciences should be scrutinized within the context of intellectual history. Thus, the interconnections between theological studies and social sciences can be revealed, and some certain science fields which make use of perception theory can become aware of the intellectual roots of the methods and techniques they have been using. Furthermore, perception theories are so effective on shaping several methods used in communication sciences that the theological origins of these perception theories should be analyzed because the analyses about how people perceive outer world have significant effects on the establishment of communication systems.
\end{abstract}

Key Words: Perception Theory, Free Will, Determinism, Nominalism, Aristotelianism

\section{Giriş}

İletişim bilimleri sahasında yapılan çalışmalar, esas itibariyle, modernliğin neden olduğu toplumsal dönüşümlere çözüm bulma çabasının birer neticesidir. Modernleşmeyle birlikte birbiriyle bağlantısız çok sayıda faktör etkileşimde bulunmaya başlar. İletişim sistemlerinin modernleşmeye paralel bir biçimde gelişmesinin en önemli sebebi, artık ulus devlet çatısı altında bir araya gelmeye başlayan toplulukları, tek bir kimlik etrafında bir araya getirme kaygısının, politikanın birinci önceliği haline gelmesidir. 
Ancak, iletişim bilimlerinde, pek çok sosyal bilim geleneğinde olduğu gibi, modernliği daha önceki toplumsal yapılardan ayıran süreksizliklere odaklanma eğilimi gözlemlenmektedir. Elbette, bir toplumsal yapıyı ya da dönemi, diğerlerinden ayıran özelliklere odaklanmak son derece işlevsel bir metottur. Fakat modern söylemin 'sıfirdan başlama ideali'nin tam olarak gerçekleştirilmesi de mümkün değildir. Zira politik yapılarda köklü değişiklikler yapılarak toplumun yeniden kuruluşu temin edilmeye çalıșılsa da, kültürel nitelikler devamlılığını sürdürür. Bu nedenle modernlik sadece süreksizlikleri ile değil, fakat süreklilikleri ile de değerlendirilmelidir.

Günümüzde modernliğin pre-modern dönem ve yapılardan devraldıkları, sosyal bilimlerin önemli çalışma sahalarından biri haline gelmiştir. Modern iletişim sistemlerinin toplum üzerindeki etkilerinin yanı sıra, toplumun yeni iletişim sistemleri ile kendisini nasıl sürekli yeniden yapılandırmakta olduğunu inceleyen iletişim bilimleri için, kullandığı teori ve ön kabullerin pre-modern kökenlerine dair farkındalık edinmek zaruridir. Böylece iletişim araçlarından çeşitli şekillerde etkilenen günümüz insanının, ne tür toplumsal dönüşüm süreçlerinde ve düşünsel tartışmalarda biçimlendiğine dair bir bilincin oluşması temin edilebilir. Zira insan içinde bulunduğu toplumsal yapının yanı sıra evren ve Tanrı kavrayışından etkilenerek toplumdaki konumunu ve kimliğini inşa eder. $\mathrm{Bu}$ nedenle, inceleme sahası olarak modern toplum ve bireyin yeni iletişim ağlarından nasıl etkilenmekte olduğunu seçen iletişim bilimleri, hem kullandığ teorilerin, hem de incelemekte olduğu nesnenin, pre-modern kökenlerini dikkate almak zorundadır. Dolayısıyla, iletişim bilimcilerin, modern birey ve toplumun niteliklerinin yanı sıra, nesnesini incelemek amacı ile kullandığ teorilerin (başta algı teorileri ${ }^{2}$ olmak üzere) gerek düşünsel, gerekse teolojik kökenlerine odaklanması gerekir. Bu çerçevede, özellikle on sekizinci ve on dokuzuncu yüzyılda hızını arttıran değişim ve dönüşüm süreçlerinin tarihsel, düşünsel ve toplumsal kökenlerinin incelenmesi, iletişim bilimleri sahasında gerçekleştirilecek çalışmaların niteliğini artıracak bir faktördür.

On dokuzuncu ve yirminci yüzyllda ortaya çıkan sosyal, politik ve ekonomik gelişmeler, modernliğin on altınc1 yüzyıldan itibaren başlayan gelişim sürecinin birer neticesidir. Bu iki yüzyıl buyunca, sadece sosyal, ekonomik ve idari yapılar değil, fakat aynı zamanda yaşam tarzı ve düşünce

$2 \mathrm{Bu}$ makalede, alg1 teorileri ile kastedilen, Bergson'un alg1 teorisinden etkisi altında geliştirilen ve iletişim bilimleri sahasında sıklıkla kullanılan 'görsel algı teorisi', 'öznel alg1 teorisi' ve 'ampirik algı teorisidir'. Psikoloji ve sosyal psikolojinin yanı sıra iletişim bilimleri ve sosyolojinin de sıkça başvurduğu bu teorilerin modern dönemdeki inşası Descartes'ten Berkeley'ye ve Bergson'a uzanan süreçte şekillenmiştir. Adı geçen alg1 teorilerinin hepsi Bergson'un felsefesinin etkisi altında olduğundan, bu makalede nominalizmin Aristotelesçilik eleştirisinden Bergson'un (1960 [1889]) 'Time and Free Will'ine (Zaman ve Özgür İrade) uzanan süreçte, alg1 teorilerinin gelişmesini olanaklı kılan toplumsal ve düşünsel süreçler incelenmiştir. 
biçimleri de köklü bir dönüşüm geçirmiştir. Ayrıca felsefenin ve sosyal bilimlerin hem problemleri, hem de metodu değişmiştir. Alg1 teorisinin on dokuzuncu yüzyılın sonundan ve yirminci yüzyılın başından itibaren sosyal bilimlerin başlıca problemlerine kılavuzluk eden bir rol oynama iddiasıyla ortaya çıkması da bu çerçevede anlaşılabilir. Düşünce tarihi çalışmaları açısından, bir şeyin başlıca problem haline gelmesini sağlayan düşünce dinamiklerinin tarihsel ve sosyal kökenleri son derece önemlidir. Zira bir sorunun sorulabilir hale gelmesi, sadece soruyu soran öznenin onu keşfetmesiyle değil, fakat aynı zamanda, sorunun sorulmasına olanak sağlayan tarihsel ve sosyal şartların da bir neticesidir. Bu nedenle, insanın dış dünyayı nasıl algıladığı ve bu algılamanın gerçeklik ile arasındaki farkın felsefe ve sosyal bilimlerin başlıca problemi haline gelmesi, uzun bir sürecin kendiliğinden bir neticesi olarak anlaşılabilir. Bu nedenle, Alfred North Whitehead (1927, 1929) ve Henri Bergson'un (1944 [1907], 1960 [1889]) çalışmalarında öznenin diş dünyayı nasıl algıladığının merkezi bir problem haline gelmesi, tarihsel ve sosyal dönüşüm süreçlerinde anlaşılmalıdır.

Bilim insanları, çoğu zaman, üzerinde durdukları sosyal zeminin kendilerine dayattıkları problemleri çözmek zorunluluğu ile karşı karşıya kalırlar. $\mathrm{Bu}$ çerçeveden bakıldığında, günümüzde gerek sosyal psikoloji gerekse iletişim bilimleri sahasında sıklıkla başvurulan çeşitli alg1 teorilerinin, modernlik koşullarında öznenin giderek ortan önemi ile bağlantısı bulunmaktadır. İnsanın dışında, kendi başına var olan mutlak gerçekliğin varlı̆̆ııın sorgulanmaya başlaması, insani etkinliğin her şeyin önünde yer almasını sağlayan şartların doğuşuna zemin hazırlamıştır. Böylece, insan, diş dünyadaki gerçekliği en net biçimde öğrenmekten ziyade, algıladığı diş dünyayı nasıl biçimlendirdiğine odaklanmaya başlar. $\mathrm{Bu}$, günümüzde rölativist düşüncelerin yaygınlık kazanmasını yol açan başlica faktördür. Ancak, insanın etkinlik sahasının devasa bir biçimde genişlemesini sağlayan bu dönüşümler zorlu süreçlerin bir sonucudur. $\mathrm{Bu}$ süreçler sadece felsefi ve bilimsel sahalar ile sınırlı değildir. Aynı zamanda, hem öznelerarasındaki (intersubjective), hem de sosyal ve idari yapilar arasındaki ilişki ve iletişim biçimlerindeki dönüşümler ile bağlantılıdır. Bu dönüşümler ekonomik ve politik dönüşümlere de yol açar. Diğer yandan, bu dönüşümler, sadece ekonomik ve politik dönüșümlerin basit birer nedeni değildir. $\mathrm{Bu}$ dönüşümler, aynı zamanda, yol açtığ1 dönüşümlerden etkilenerek yeniden yapılanmaktadir.

Birbirlerini karşıl1klı olarak etkileyen pek çok faktörün bir neticesi biçiminde sürekli yeniden yapılanan modernliği ve modern düşünceyi anlamak ve açıklamak için, hangi problemlerin doğmasına öncülük ettiğine odaklanmak etkili bir araştırma metodu olarak kullanılabilir. Problem sadece düşünürün kendi bireysel etkinliği ile icat ettiği bir şey değildir. Problem, aynı zamanda, tarihsel süreçte ortaya çıkan ve düşünür tarafindan keşfedilen 
bir şeydir. Problemin doğuşu, kökleri bazen çok uzun süreleri kapsayan gelişim süreçlerinin doğal bir sonucudur. $\mathrm{Bu}$ nedenle, düşünürler, çözmek zorunda kaldıkları problemler ile karşı karşıya kalırlar. Dolayısıyla, bir dönemin anlaşılması için, o dönemde çözülmeye çalışılan problemler incelenebilir. Ayrıca, başka zaman ve mekânlarda ele alınan çeșitli problemler, farklı tarzlarda ele alınabilir. Problemi ele alış tarzlarındaki dönüşüm de, dönemin anlaşılması açısından çeşitli olanaklar sağlar. $\mathrm{Bu}$ çerçevede, çalışmamızda, modernlik ile birlikte, insanın dış dünyayı nasıl algıladığına giderek daha fazla önem verilerek, felsefi ve bilimsel çalışmaların başlıca problemlerinden bir olmasına yol açan sosyal, tarihsel ve düşünsel süreçler ve birbirleriyle bağlantıları incelenmektedir. Böylece, bilimsel keşiflerin kendi başlarına gelişmeyi sağlayan bir faktör olmadığı, fakat ayrıca, kendisinin de sosyal ve düşünsel dönüşümlerin bir sonucu olduğuna dikkat çekilmektedir. Ayrıca, Nominalizmin Aristotelesçilik eleştirisi ile başlayan ve ilk önce Luther ile Erasmus daha sonra ise Descartes ile Hobbes arasında gerçekleșen 'özgür irade ve determinizm problemi'ne dair tartışmaların modern düşüncenin biçimlenişini nasıl etkilediği vurgulanarak, günümüzdeki çeşitli bilimsel problem ve tartışmaların teolojik tartışmalar ile bağlantısı ortaya koyulmaktadır.

\section{Algı Probleminin Tarihsel ve Sosyal Kökenleri}

'Algı'nın başat bir problem olarak ortaya çıkmasını sağlayan tarihsel ve sosyal şartlar, Kutsal Roma Cermen İmparatorluğu'nda (Holy Roman Empire), 1618 ile 1648 yılları arasinda, Protestanlar ile Katolikler arasında yaşanan Otuz Yıl Savaşları'ndan (Thirty Years' War), 1756 ile 1763 yılları arasında vuku bulan Yedi Yıl Savaşları'na (Seven Years' War) kadar uzanana bir süreçte ilk evresini tamamladı. $\mathrm{Bu}$ süreçte, günümüzde 'Avrupalılık' olarak adlandırılan olgunun kültürel arka planı biçimlendi. On yedinci yüzyıla kadar çok sayıda politik yapıdan teşekkül eden Avrupa'da politik merkezileşme süreçlerinin yaşanmaya başlamasıyla, iktidar belirli merkezlerde toplanmaya başladı. Böylece politik egemenliklerin sayısı da giderek azaldı. Bu zamana kadar, Vatikan, Avrupa'nın parçalı politik yapısından faydalanmak suretiyle egemenliğini pekiştirme olană̆ına kavuşmuştu. Ancak, daha sonraları XIV. Louis (Louis XIV) ve II. Friedrich (Frederick the Great) Papalık ile karşılaştırıldığında çok daha büyük ve güçlü politik egemenlikleri gerçekleştirdi (Köhler, 1903; O'Brien, 1931). Hem XIV. Louis hem de II. Friedrich kültürel sahada gerçekleştirdikleri yenilikler ile daha önce görülmemiş gelişmelerin gerçekleşmesine olanak sağlad1 (Bourke, 1947; Jeffrey, 1912; Sandman, 1977; Garlick, 1997; Isherwood, 1969). 'Avrupalılığın' farklı politik merkezlerin egemenlik mücadelesi ile şekillenmesi de bu süreçte gerçekleşti. Çok sayıdaki farklı etnik grubun belirli politik merkezlerin potasında eritilerek ulusal kimliklerin 
inşa edilmesi de bu dönemde gerçeklești. Birbirleri ile iletişim kuramayacak kadar farklı lehçeleri konuşan yerellikler, kültürel birlikteliklerini, politik merkezlerin etrafinda bir araya gelerek temin ettiler.

On sekizinci yüzyılın ortasında tüm Avrupa'da popülasyon hızla artmaktayd1. Dünyanın diğer pek çok sahasıyla ticari bağlar kuran Avrupa bir yandan politik organizasyonunu istikrarlı hale getirmeye çalışırken, diğer yandan hem ticari, hem de üretim sistemlerinde yaşanan dönüşümleri takip etmeye çalışıyordu. Ancak, yine bu dönemde, bizim bugün modern problemler olarak nitelendirebileceğimiz yeni olgular ile karşı karşıya kalındı. Din ve gelenek toplumsal yapının sürdürülebilmesi için gereken çeşitli işlevlerini yerine getirmekten giderek uzaklaşıyordu. Özellikle Kuzey Avrupa'da dine ve geleneğe ilişkin şüpheler artmaktaydı. Şüphesiz ki, on sekizinci yüzyıl Avrupa'sında, sadece dinsel ve geleneksel otoriteyi sarsmay1 amaçlayan bir eğilimin mevcut olduğu iddia edilemez. Daha çok, kendisini tartışılmaz ve hakikati kendinden menkul bir biçimde sunan geleneksel ve dinsel kurumların sorgulanamazlığının, toplumun yeni gelişmelere ayak uydurmasını engelleyici rolünden rahatsızlık duyulmaktaydı. Diğer yandan, yeni kuşaklar ile ataları arasındaki ayrım giderek daha belirgin hale gelmekteydi.

Ancak toplumların işleyişini sağlayan faktörler birbirleriyle karmaşık bir biçimde bağlantılı, çeşitli yapıların bir araya gelmeleriyle oluşur. Bunlardan birinde herhangi bir değişikliğe gidildiğinde diğerleri de çeşitli şekillerde etkilenir, değişir ve dönüşür. Bu değişim ve dönüşümler çoğu zaman kontrol edilebilir değildir. Değişimi gerçekleştirmek isteyenin arzu ettiğinin tamamen dışında sonuçların doğması, çoğu zaman, kaçınılmazdır. On sekizinci yüzyılda, daha önceleri değişmez ve istikrarlı görünen pek çok olgu, yeni kuşaklara, değiştirilebilir ve yerine yenisi konulabilir gibi görünmeye başlar. Gelgelelim, bu değişim, kaygının da doğmasına neden olan bir olgudur. Eski olanın "deneyimlenmişliğì" ve "tekrarlanmışlığı", güven vermesini sağlar. Yeni olanın nelere yol açabileceği, ondan kuşku duyulmasına neden olur. On sekizinci yüzyıl Avrupa'sında, farklı kuşaklar kendilerini çevreleyen dünyayı yorumlamaya çalışırlarken, yeni durum karşısında kendilerine yardımcı olabilecek az sayıda kurum ve deneyim ile karşı karşıyaydılar. Kendi aidiyetlerini giderek daha fazla sorguluyorlardı. Ayrıca, yeni kurum, gelenek, bilgi ve deneyimlerin gerekliliğinden, giderek daha fazla emin olmaya başliyorlardı. Bunun yanı sıra, kendilerine yol gösterici olabilecek herhangi bir kaynağa sahip olmadıklarını da hissediyorlardı. Dolayısıyla süreç, değişimin nasıl gerçekleșeceğinde düğümlenmeye başladı. ${ }^{3}$

$3 \mathrm{Bu}$ çerçevede, John Locke'un (1632-1704) insanlığın tarihsel deneyim referanslarını dayanak göstermeden, politika felsefesini geliştirdiğine dikkat çekmek gerekmektedir. 
XIV. Louis'ten itibaren Fransa'da başlayan merkezileşme, Devrim'in şartlarını olgunlaştırarak kontrolsüz değişimi Fransa'ya dayattı. II. Friedrich ise sarayını bir kültür merkezine çevirerek bağımsız Alman Prensliklerini, önceleri kültürel, daha sonra ise politik olarak kendisine entegre etmeye çalıştı. Bu sayede lokal otonomiler giderek erozyona uğradı (Stephens, 1974). Yeni kuşaklar, bir yandan değişimin yarattığ 1 heyecana kendilerini kaptırırken, diğer yandan her an bir şeylerin ters gidebileceğinden endişe ediyorlardı. Onlar için, insanlığın on sekizinci yüzyılda yaşanan her şeyi ilk defa deneyimlediği şüphesizdi. Bu nedenle, on sekizinci yüzyılın Avrupalı genç kuşakları kendilerinden başka bir rehbere sahip olmadıklarını, giderek daha fazla, hissediyorlardi.

Nisbet (1986) "The Making of Modern Society" (Modern Toplumun İnşası) adlı eserinde batı toplumları tarafından inşa edilen modern toplumun başlıca niteliklerinden birinin, devlet ile birey arasındaki aracı kurumları ortadan kaldırarak, bunları doğrudan ve karşılıklı ilişkilendirmek olduğunu iddia eder. Bu manada, Alman idealizminin ve Fransız düşünürlerinin "biz" nosyonunu giderek daha fazla kullanarak, temel referans kaynağı haline getirmeleri, on sekizinci yüzyıldaki gelişmeler hakkında bize fazlasıyla öngörü sağlar. Kant, bu anlamıyla, "biz" (wir [we]) nosyonunu en fazla kullanan düşünürlerdendir (Pinkard, 2002: 19). "Biz" ne yapacaktır? Onlara göre "biz" kendi kaderini kendisi çizecektir. Onlar için "biz" geçmiş ve gelenekten bağımsız olarak deneyimine başvurulacak ve yeni bir dünya yaratacak tek özne ve referans kaynağıdır. Bu bakış açısı Avrupa'da devrimci bir atmosferin yayılmasına olanak sağlayan yegâne olgudur. Yine bu dönemde etnik kimlikler daha önceki dönemlerde politik anlamları barındırmamaktayken, giderek Almanlık, Fransızlık ve İngilizlik politik bir içeriğe sahip olmaya başar. Bunların kendi içinde bütüncül bir yapı arz etmeleri her şeyden önemli hale gelir. Hegel felsefesinde en mükemmel haline kavuşan 'Alman İdealizmi'nde, bütünlüğün gerçekliğin bizatihi kendisi olduğunun 1srarla vurgulanması da bu çerçevede anlaşılabilir (Pinkard, 2002: 243). Hegel'in her şeyin birbiriyle bağlantılandığı, farklı bölümlerden oluşmayan, sosyal bir yapının varlığını ve inşa edilmesi

Resnick (1984), Locke'un herhangi bir antik anayasaya, geleneğe ya da tarihsel politik düşünceye başvurmaksızın, politik teorisini geliştirmiş olduğuna dikkat çeker. Gerçekten de Locke (1988 [1689]) 'Two Treatises of Civil Government' adlı eserinde politika felsefesini insani deneyimin tarihine başvurmadan geliştirir. Zira Locke için doğal haklar ve kuvvetler ayrılığı gibi ilkeler tüm insani deneyimin üzerinde duran evrensel yasalardır. Bu çerçevede Glat (1981: 3), Locke'un İngiliz tarihine dair hiçbir şey yazmadığına dikkat çekerek, gerek İngiliz yasalarının tarihine gerekse İngiliz politik kurumlarının tarihine karşı ilgisiz bir düşünür olduğunu vurgular. Zira Locke, çağının ruhuna uygun bir biçimde, yeni bir başlangıcın arifesinde bulunan toplumunun geçmişinden ve çeşitli uygulamalarından ziyade, gelecekte neler yapacağı ile ilgilidir. 
gerektiğini 1srarla vurguluyor olması, döneminin eğilimi ile paralellik arz eder.

On sekizinci yüzyıl değişimi bir an önce sağlamak için gerçekleştirilen atılımlar ile dolu bir yüzyılken, on dokuzuncu yüzyıl sağlanan değișim ve dönüşümlerden kuşku ve tedirginliklerin etkili olmaya başladığı bir dönemdir. Devralınan tüm sosyal yapıların derinden sarsıldı̆̆ı ve yerlerine yenilerin yerleştirildiği bir yüzyılda Avrupalı uluslar, yeni durumun yeni deneyimler ve bilgi yapılarını gerektirdiğini şiddetle hissediyorlardı. Aşkın (transcendental) bir referans kaynağına başvurmadan, sadece kendilerine (bize) dayanarak yeni durumun gerekliliklerine cevap verme çabası, insanın toplumsal yapının biricik belirleyicisi ve inşacısı olduğuna yönelik inancın güçlenmesine neden oldu. 'Ínsan' inşa faaliyetini gerçekleştirirken sadece kendi k1lavuzluğuna güven duyabilirdi. Bu sayede, tarih de bir ilerleme süreci olarak anlaşılmaya başladı. Geçmiş ile bugün ve gelecek arasında derin farklılıkların olduğu, bu nedenle de eski deneyimlerin bugün ve geleceğin ihtiyaçlarına cevap veremeyeceğine dair inanç giderek pekiști. Yine bu süreçte, insanın diş dünyadaki gerçekliği doğru bir biçimde anlaması ve öğrenmesi için neler yapması gerektiğinden giderek uzaklaşılarak, diş dünyanın insan tarafından nasıl faklı biçimlerde algılandığına yönelik ilgi arttı. İnsani algılamanın bir yaratım süreci olduğu ve insanın dış dünyayı birbirinden farklı şekillerde algılayabileceği genel bir kabul gördü. Așkın referanslar bir kenara birakılırken, insanların öznelerarası etkinliğinin sonucu olarak oluşacak uzlaşımlar temel referanslar haline geldi. Tüm bunlar ise Ockhamlı William ile başlayan ve 'Tanrı' ile 'insan' arasındaki vadiyi aşılmaz bir biçimde genişleten nominalist devrimin doğal neticeleriydi.

\section{Nominalist Devrim ve Aristotelesçilik Eleștirisi}

Orta Çăg, Hıristiyanlığın yanı sıra pagan felsefenin de egemen olduğu bir dönemdir. Endülüs'ün İber Yarımadası'ndan silinmesiyle antik felsefenin Arapça çevirileriyle tanışan Avrupa, Hıristiyanlık ile pagan felsefenin bir sentezini oluşturdu. Ancak bu çok sayıda teolojik tartışmayı da beraberinde getirdi. İnsanın etkinlik sahasının sınırlarının ne kadar olduğu ve Tanrı'nın gücünün sınırlarının nereye kadar uzandığı başlıca meselelerdendi. Kaderi Tanrı tarafından belirlenmiş insanın, nasıl yine Tanrı tarafından cezalandırılabileceğine dair tartışmalar Avrupa düşünce dünyasının temel parametrelerini de belirledi. Zira insan iradesinin özgürlüğü ile determinizm arasındaki tartışma her ne kadar eski bir problem olsa da, Hiristiyanlık ile pagan felsefenin sentezlenmesi problemi yeni bir boyuta taşıdı.

Skolastik felsefe, esas itibari ile realizmin klasik biçiminden derin izler taşır. Evrenin tek bir bütünlük olduğu ve parçalarının birbiriyle uyumlu 
olduğu inancı hem skolastikler hem de Platonculuk ve Aristotelesçilik tarafından paylaşılan bir görüştür. Bu anlamıyla, evren her şeyin bir araya geldiği bir bütünlüktür. $\mathrm{Bu}$ görüşe göre, bireysel varoluşlar evrenin birer parçası ya da evrensel bütünlügün bireysel yansımaları biçiminde anlaşılır. Böylece doğa akıldan ayrılamayacağı gibi, akıl doğaya yansır. ${ }^{4}$ Doğa da aklın bir çeşit yansımasıdır. Doğadaki şeyler akılsal bir harmoni ile bir arada var olurlar. Bütün türler akılsal bir tutarlılıkla bir arada bulunur. Akılsal yapının dışında yer alan bir şeyin doğada mevcut olması düşünülemez. Doğada Tanrı'nın çeşitli yansımaları mevcuttur. Zira Tanrı'nın akıl dışı olabileceği düşünülemeyeceğinden dolayı, doğanın akılsal tutarlılığ1 ve yapıs1 ile Tanrı arasında bir uyum mevcut olmalıdır. Bu nedenle, Tanr1 doğanın akılsal yapısının anlaşılması ile idrak edilebilir (Gillespie, 2008: 20). Dolayısı ile doğanın yasaları Tanrı'yı anlayabilmek için kullanılabilir. Tanrı'yı anlamak için kutsal metinler kullanılabilse de, doğanın mantıksal yapısının kavranmasıyla Tanrı'ya ulaşmak mümkündür. Zira Tanrı, mantıksız ve akıl dışı olamayacağından, doğanın yasalarına tabidir. Ancak, Tanrı müdahalede bulunamayacağ 1 doğa yasalarına tabi kılındığında, yasa koyucu kendisi olduğunda dahi, bu yasaları değiştirebilecek güce sahip olmadığı kabul edilmek zorunda kalınır (Basinger, 1983: 31). Bu da yeni teolojik problemlerin doğmasına yol açar.

Aristotelesçilik, Avrupa düşünce dünyasında, Reformasyon öncesinde ve sonrasında, çeşitli şekillerde, etkili olmuştur. ${ }^{5}$ Aristotelesçilik Hıristiyan

4 Bayram (2009) modernleşme süreçleri ile bilgi yapılarının ve disiplinlerinin biçimlenişleri arasındaki paralelliklere dikkat çeker. İktidar ile bilimin bütünleşmesi ile insanın doğa üzerindeki egemenliğinin, daha önce hiç olmadığı kadar, mutlak bir biçimde tesis edildiğini düşünür. Ayrıca Bayram'a göre (2009: 22), modern bilimdeki doğanın kontrolünü sağlayan mekanizmalar, sosyal bilimlerin tesisiyle toplumu denetlemek için kullanılmıştır. Tüm bunların gerçekleşmesi için "universitas"tan "societas"a geçilmesi gerekmiştir. Dünyevi rasyonellik Tanrı'nın iradesinin yerini aldıkça modern tahakküm tarzları tüm toplumu kuşatacak bir biçimde işlevsel hale gelmiștir. İnsanın her türlü eyleminin meşrulaştırılması ve tek referans kaynağının insanlar arasındaki iletişime indirgenmesi için doğa bilimlerinin belirleyici olmasına ihtiyaç duyulmuştur. Bunun sağlanabilmesi için vazgeçilmez olan “universitas"tan "societas"a geçiş sürecinde gerçekleșen dönüşüm, "sosyal eylemlerin haklılaștırılması gereksiniminin ... referanslar farklı olan yeni bir etik anlayışla giderilmesini gündeme getirmiştir. Modern dönemden günümüze ana felsefi çalı̧̧maların tümünün kapsaminda yer alan etik arayış (bireycilik, faydacılık, varoluş̧̧uluk vb.), bu ihtiyacı gidermek üzere ortaya konmuştur" (2009: 11).

5 Freedman (1993: 235), Aristoteles'in çalışmalarının, Avrupa düşünce dünyasındaki etkisini belirtmek için, 1500 ila 1650 yılları arasındaki dönemi kapsayan Reformasyon dönemi boyunca, Avrupa okullarında kullanılan başlıca kaynak olduğunu vurgular. Ona göre, gerek felsefeciler gerekse felsefe kurumları, Aristoteles'in eserlerini kullanıp kullanmamak konusunda herhangi bir seçeneğe sahip değillerdi. Aristoteles'in eserlerini kullanmaları Aristotelesçi olmalarından kaynaklanmıyordu. Aristoteles'in eserlerini sadece pratik gerekçelerden dolayı kullanıyorlard. Zira Aristoteles'in eserleri metafizik, fizik, etik, aile hayatı, politika, retorik, gramer ve mantık eğitiminde yaygın bir biçimde kullanılıyordu. 
düşünürler arasında etkin oldukça, Kilise'den kısmen bağımsız bir biçimde yeni düşünce tarzları da gelişmeye başlar. Ancak, pagan düşünürlerin etkili olmaları, İslam dünyasında Gazali'nin felsefe eleştirilerine benzer eleştirin dile getirilmesine neden olur. ${ }^{6}$ Aristotelesçiliği ve onun Hıristiyan dünyas1 ve düşüncesi üzerindeki etkilerini etraflıca eleștiren düşünürlerden en önemlilerinden biri Ockhamlı William'dır (1287-1347).

Ockhamlı William, Thomas Aquinas'ın (2007 [1271-72]) (1225-74) 'Commentary on Aristotle's Politics' (Aristoteles'in Politikasina Şerh) adlı eseriyle etkinlik kazanan Aristotelesçiliğe, yeni bir Tanrı kavrayışı ile karşı çıkar. Aziz Thomas, tüm felsefe tarihini sistematik bir biçimde yeniden yapılandırabilecek kadar büyük bir dehaya sahiptir. ${ }^{7}$ Ayrıca, Aziz Thomas, yaratılışın epistemolojisini Aristotelesçi mantığın 'akıl' anlayışı içinde açıklayabilecek kadar yeteneklidir (White, 1978: 50). Ancak, William of Ockham, nominalizme öncülük eden Roscelin, Peter Abelard, Ghentli Henry, Duns Scotus'un çalışmalarını detaylı bir biçimde takip etmişti. Bu sayede, Ockhamlı William yeni bir metafizik ve teolojinin inşasını sağlayacak çalışmalara imza atmasına neden olacak geniş bir çevreden faydalanma olanağı edinmişti. Ona göre, iman sahibi olmak, Tanrı'nın 'her şeye kadir' (omnipotent) gücünü idrak edebilmemiz için yeterlidir (Gillespie, 2008: 22).Tanrı'nın gücü, ne doğa yasalarıyla ne da başka herhangi bir şey ile sinırlanamaz. Tanrı her şeye gücü yetendir. Bu nedenle Tanrı kendi koyduğu kuralları istediği zaman, baştan aşağı, yeniden tasarlayabilir. Tanrı için her şeyi yapmak mümkündür (Pegis, 1948: 454). Nominalistlere göre, bizler bir şeyin mantıklı ve uyumlu olduğunu düşünüyorsak, Tanrı onu yeniden bambaşka biçimde tasarladığında da, onun mantıklı ve uyumlu olduğunu düşünürüz. Bu nedenle, bizim bir şeyin akı1 ile uyumlu olduğunu düşünmemizde Tanrı sayesindedir.

6 Arslan (2007), hem Aristotelesçi Hıristiyan felsefecilerin, hem de İslam felsefecilerinin, Aristoteles'i kendi dinlerine uyarlamak amaciyla, gerçekte olduğundan farklı biçimde yorumlamaya çalıştıklarını, ancak bu çabalarının Aristoteles'in Tanrı öğretisi ile bir paralellik arz ettiğini kabul etmenin mümkün olmadığını belirtir. Arslan'a göre, Gazali İslam felsefecilerinin tersine Aristoteles'in eserlerinden "ne dünyanın yaratılmış olduğu, ne Tanrı'nın evrenle ilgili olarak onun gerçek faili olduğu ne de tanrisal bilginin evrenin bilgisi içinde bulunduğu sonuçlarını çıkarmayarak Aristoteles'in bu konudaki görüşlerini daha doğru anlamıştır" (2007: 203). Gelgelelim İslam Dinini felsefe vasıtası ile anlama ve açıklama çabalarını tamamen ortadan kaldıracak bir düşünüş tarzına yol açmamak gerekir. Bu çerçevede, Toktaş (2004: 187) "İlam Düşüncesinde Felsefe Eleş̧tirileri" adlı eserinde, Gazali'nin Aristoteles ve Platinos'un öğretilerine dayanan Meşşai okuluna yönelik eleştirilerini sıraladıktan sonra, bu eleştirilerin her türlü felsefeyi içerecek bir biçimde yorumlanarak, aşırı uçlara taşınmaması gerektiğini vurgular.

7 Arslan (2007: 202), Aristoteles'in Doğu'da Farabi, Batı'da ise Aziz Thomas üzerinde önemli bir etkide bulunduğunu belirtir. Ona göre, Aziz Thomas Aristoteles'in salt düşünce biçiminde betimlediği Tanrı'yı Hıristiyanlığa uyarlamak adına, saf 'varoluş' (existence) olarak tanımlayarak önemli bir girişimde bulunmuştur. 
Aristotelesçiliğin derin etkisi altındaki skolastik Tanrı kavrayışı gerek Tanrı'y1 gerekse onun yaratımlarını tek bir akla ve mantığa tabi kılarak, onları zorunlu bir biçimde uymak zorunda oldukları yasalara bağımlı hale getirir. $\mathrm{Bu}$, Tanrı ile insan ve diğer yaratımları arasındaki mesafeyi minimuma indirir. Nominalistler için ise Tanrı uymak zorunda olduğu herhangi bir şey ile sınırlanamaz. Onlara göre, Tanrı sınırsız bir güce sahip olduğundan, her şeyi yeniden tasarlayabilir. Akıl ve mantık da Tanrı tarafından defalarca tasarlanabilir. Burada Platonizm ile Aristolelesçilik arasındaki ayrım bir kez daha karşımıza çıkar. Platonizm panteist eğilimleri daha fazla barındırır. Tanrı her şeyde duyumsanır ve her şey O'nun nedensel gücünün ürünüdür (Hedley, 1996: 70).

Ancak, sorun Tanrı her şeyin nedeni olarak kavramsallaştırıldığında çözülmüş olmaz. Zira bu defa da, Tanrı insanların işlediği günahların da nedeni haline gelir. Bu sayede problem başka bir boyuta taşınmış olur. Nominalistlerin Tanrı ile yaratımları arasında derin bir uçurum yerleştirmeleri, insanın etkinlik sahasını genişletir. Dolayısıyla, önce Lüterciliğe daha sonra ise Kalvenizm'e (Calvinism) kapı açılmış olur. Luther, Katolik inancının tüm yasaklarını bir kenara bırakarak doğadan keyif almaya, yemeğe, içmeğe ve cinselliğe konan yasakları kaldırmaya yönelir. Lütercilik için doğa ilahi bir armağandır ve ondan zevk alınmalıdır (Gillespie, 2008: 127). Nominalizm asıl gerçekliğin bireysel şeyler olduğunu ileri sürerek, kişinin gündelik pratiklerini gerçekleştirdiği sahada daha serbest bir biçimde hareket etmesine olanak sağlar. Ayrıca, nominalizm akıl yürütmenin hiçbir şey olmadığını, fakat imajların bir araya getirilmesinin ve isimlerin var olduğunu iddia eder. Böylelikle, düşünürler insani duyumsamanın önemine daha fazla ilgi göstermeye başlar. Bu sayede, Hume, Kant ve Bergson'un insani algılamanın yapısına odaklanmalarına ve on dokuzuncu yüzyılın sonu ile yirminci yüzyılın başından itibaren alg1 teorisinin temel referans kaynaklarından biri haline gelmesine neden olacak yol açılmış olur.

\section{3. Özgür İrade ve Determinizm Tartışması}

Nominalistlerin Tanrı ile yaratımları arasında derin bir boşluk oluşmasına neden olan Tanrı kavrayışları, Rönesans'ın ve hümanizmin doğuşuna öncülük etmiştir. İnsanın evrende Tanrı ile aynı akıl ve mantığın yasalarına tabi olduğu görüşünün yerine ikame edilen Nominalist Tanrı nosyonu, insana etkinlikte bulunabileceği daha geniş bir saha açar. Bu sayede Rönesans'in ve hümanizmin babası sayılan Francesco Petrarch (1304-74) ile birlikte, insani bireyselliğe daha fazla önem verilmeye başlar. Eserlerinde insanın bireyselliğini işleyen Petrarch, tıpkı Dante ve Chaucer ve diğer on dördüncü yüzyıl yazarları gibi, ruhu ve özneyi anlayabilmek için edebiyat ve sanatı kullanmaya başladı (Stock, 1995: 725). Petrarch'ın (1974 
[1347-67], 1976) şiir ve mektuplarında bireyselliği işlemesi ile giderek insanın özgünlügüune daha fazla odaklanıldı. Özellikle Petrarch'ın 1348 yılında Cicero'nun mektuplarını keşfetmesi ile başladığı, kendi mektuplarını derleme girişimi, kişisel özgünlügün sanattaki önemini arttıran etkilere yol açtı (Zak, 2010). Petrarch 'Sokrates' adlı kurgusal bir karakter yaratıp, onunla mektuplaşarak kendi öznelliğini ve özgünlüğünü sergiledi (Wilkins, 1964: 804). Tanrı'nın insanın her anını gözleyen ve insan ile birlikte tek bir harmoninin parçası olduğuna inanılan skolastik görüşlerin politik neticesi, toplumsal bütünlüğün mutlak bir biçimde tesis edilmesini beraberinde getiriyordu. Ancak, Tanrı'nın insani etkinliklere ilgisiz olduğu ve insanın kendi başına olduğu inancı yaygınlaştıkça, Tanrı, insanın bireyselliğinde aranmaya başlarken, insan da 'yaşam evreni'nde (lebenswelt [life-world]) giderek daha serbest bir biçimde hareket edebilir hale geldi.

Luther (1985 [1525]), Petrarch'ın görüşlerini birkaç adım öteye taşıdı. Luther için de Tanrı hem sınırsız güç sahibiydi, hem de iyiydi. Buna karşı, hem Erasmus'un hem de Aristoteles'in Tanrı'sının 'uykuda' olduğunu ileri sürdü. Her şeyi akla ve insanlığa ihale eden bir Tanrı nosyonunun Hıristiyanlığın özü ile bağdaşmadığı inancinda olan Luther, kendisini Hıristiyanlığ paganizmin kalıntılarından kurtarmak ile vazifelendirdi. Ona göre, gerek Erasmus'un Tanrısı, gerekse Aristoteles'in Tanrıs1, evreni ve dünyayı bir defa yaratmış ve her şeyle birlikte kendisini de aklın yasalarına tabi kılarak uykuya dalmıştır. Kendi Tanrı nosyonunda bunlara yer yoktur. Evrende olan her şey ve her türlü insani etkinlik sadece Tanrının arzusunun bir sonucudur. Tanrı her șeyi yeniden tasarlama imkânına her zaman, sahiptir.

Tanrı'nın her şeyin ortaya çıkışında başlıca faktör olduğu iddiası, kötülükten de Tanrı'nın sorumlu olup olmadığı sorusunun doğmasına neden olur. Böylelikle, "teodise problemi" din felsefesinin en önemli problemlerinden birisi haline gelir. İlk defa Epikür tarafından ortaya konan ve problem 'tanrının her şeye kadir olmasına rağmen, neden kötülüğe mani olmadığı' sorusundan doğmuştur. Kötülüğün sebebi Tanrı ise, yaratımı olan insanları cezalandırması haksızlık değil midir? Ancak, eğer kötülük, Tanrı'nın etkinliğinin dışında gerçekleşiyor ise, evrende Tanrının müdahale edemediği bir otonominin varlığı kabul edilmiş olmaz mı? Bu durum, Tanrının her şeyin belirleyicisi olduğunu savunan deterministler ile özgür iradenin varlığını savunanlar arasında yoğun bir biçimde sürdürülen tartışmalara neden olur. Ancak meselenin sadece teolojik tartışmalar ile sınırlı kalmadığına dikkat çekmek gerekir. O'Malley (1974) de 1524 yılında Erasmus'un Lüterci öğretiye meydan okuyan "De libero arbitrio diatribe sive collatio" (İradenin Özgürlüğüne Dair) adlı metni ile başlayan ve bir yıl sonra Luther'in "De servo arbitrio" (İradenin Esaretine Dair) adlı cevabiyla devam eden tartışmanın sadece teolojik bir tartışma olmadığını, fakat aynı 
zamanda hümanistlerin Reformasyonun sonuçlarına karşı çıkışlarında kullandıkları kimi argümanların, günümüz tartışmalarını da etkilediğini belirtir. Gerçekten de Reformasyon ile hümanist gelenek arasında devam eden çoğu tartışma, modernliğin temel özelliklerinin biçimlenişimde son derece etkili olmuştur.

On altıncı yüzyılda yașanan tartışmalar göz önüne alındığında, iç içe geçmiş düşünce dinamikleri ile karşı karşıya kalırız. Erasmus (1985 [1524]), nominalistlerin Aristotelesçilik eleştirisinden feyz alarak düşüncelerini geliştirmiş olan Petrarch'ın hümanizminden etkilenerek diyalektiğe ve retoriğe önem vermiş ve Antik Yunan düşünürlerinden ziyadesiyle faydalanmıştır. Aynı gelenekten etkilenen Luther ise, hümanizme karşı determinist düşünceler ileri sürmüş ve Yunan felsefesinin Hıristiyanlık üzerindeki etkilerine karşı çıkmıştır. Bu sayede özellikle Luther'in son yargının Tanrı'ya bırakılarak, hali hazırda yapılacaklara odaklanmanın her Hıristiyan'ın birinci vazifesi olduğunu 1srarla vurgulaması, dünyevi bir dünya görüşünün yaygınlaşmasına yol açarak, çalışma ahlakının gelișmesine neden olmuştur. ${ }^{8}$ Diğer yandan Erasmus gibi hümanistler ise, Petrarch'ın etkisiyle, insanın bireyselliğine odaklanmış ve bu bireyselliği sanatın konusu haline getirmiştir (Panofsky, 1969). Hümanizmin bireyselliğe ve özgelişime odaklanması ise Avrupa genelinde pek çok politik, sosyal ve ekonomik dönüşümü, beraberinde getirmiştir. ${ }^{9}$

Tüm bunların yanı sıra, deterministler ile özgür iradeye inananlar arasındaki tartışmalar modern düşüncenin dinamiklerini şekillendirmiştir. Garip bir biçimde, iki farklı yaklaşımın tek bir potada eridiği gözlemlenir. Deterministler, nominalizmden Kalvenizm'e, daha sonra ise Protestanlığa giden yolda, Tanrı'nın varlığının her şeyi içerdiği ve O'nun, her şeyi en başından itibaren yeniden yaratabilme kudretine sahip olduğu iddiasıyla, insanın yapması gerekenin sadece etik davranmak olduğu, görüşündeydiler. Onlara göre Tanrı insanı sürekli soruşturan bir 'savcı' değildir. İnsan Tanrı ile aynı mantık ve akıl ilkelerine tabi olmadığından, kendi başınadır. İnsan, sadece, Tanrı'nın hükmüne tabidir. Hüküm gününü beklerken etik davranmak ve kutsal yazılara (scripture) kulak vermek ile yükümlüdür. Zira

8 Max Weber (2008: 128 [1908-20]) (1864-1920) Luther'i referans göstererek, yazgının Tanrı'ya bırakılarak, sorumluluğun etiğine göre davranmanın, modern Alman politik yapısının biçimlenişinde hayati bir rol oynadığını belirtir.

9 Hümanizmin politik, sosyal ve ekonomik etkileri büyük bir çeşitlilik ihtiva eder. Bu etkiler, en mükemmel bir biçimde Rönesans Floransa'sında gözlemlenebilir. Lorenzo de' Medici (1449-92) hümanist akımın derin etkisi ile insanın yaratıcı etkinliğine önem vermiş ve Floransa'yı yeniden biçimlendirirken hümanist dünya görüşünden faydalanmıştır. Gerçekten, Lorenzo rasyonel kent planlamasının hümanist kavramları çerçevesinde, doğru biçimde bilgilendirilmiş olduğundan, Floransa insani yaşam için ideal bir yapı kazanmıştır (Kent, 2004: 71). 
Tanrı kutsal metinler vasıtasıyla insan ile iletişime geçer (Gillespie, 2008: 117). Özgür iradeye inanalar ise, Tanrı'nın keyfi bir biçimde davranamayacağını, bu nedenle de mantığa ve akla dayanması gerektiği iddiasındaydılar. Tanrı her şeyin sebebi olarak kavramsallaştırıldığında, insanın gerçekleştirdiği kötülüklerden de sorumlu hale getirileceğinden, insanın cezalandırılmasının mümkün ve adil olamayacağını düşünüyorlardı. $\mathrm{Bu}$ nedenle de insani deneyime ve insani etkinliğe önem verdiler. Ayrıca, bu,Erasmus'un 'esas olanlar' (essential) ile 'esas olmayanlar' (nonessential) arasında yaptığı ayrımın, temelde, pratik ve varoluşsal varlığa odaklanmasına dayanmasının ve doktrinin gelişiminden çok kişisel gelişime önem vermesinin de temel sebebidir (Jarrott, 1970: 146). İnsani etkinliğin iyileşebilmesi için, Tanrı'nın her şeyin sorumlusu olarak kavramsallaştırılmaması gerektiğine inandılar.

Ancak, tüm farklılıklarına rağmen, her ikisi de, insanın etkinlik sahasının genişlemesine neden oldu. Özgür irade savunucuları, kötülük ile Tanrı'y1 birbirinden kesin bir biçimde birbirlerinden ayırarak, insani etkinliğin iyileştirilmesi gerektiğini ileri sürdü. Deterministler ise Tanrı'nın mutlak gücüne inandıklarından, O'nun her türlü insani etkinliğin belirleyicisi olduğunu iddia ettiler. $\mathrm{Bu}$ sayede Tanrı ile insanın ayn kurallara tabi olmadıklarını kabul ederek, bu ikisi arasında derin bir vadi açtılar. $\mathrm{Bu}$ sayede, insanın Tanrı'nın iradesi karşısında çaresiz olduğunu ve son yargıyı beklerken etik davranması gerektiğini ileri sürdüler. Modernliğin temel özelliklerinin biçimlenmesinde etkili olan 'çalışma ahlakı' da Tanrı iradesi karşısında çaresizce beklerken etik davranmaya çalışanların (özellikle Almanya'da) yaşam karşısındaki duruşu olarak ortaya çıktı (Means, 1966: 373).

Dolayısıyla, günümüzde de, çeşitli tarzlarda karşılaştığımız deterministler ile özgür iradeye inananlar arasındaki tartışmalar, esas itibarıyla, teolojik kökenlidir. Benzer bir biçimde, genelde, politik özellikleri ile ele alınan Hobbes ve Descartes arasındaki tartışma da teolojik kökenlidir. $\mathrm{Bu}$ iki felsefecinin de modernliğin temel yapı taşlarının şekillenişinde başat bir rol oynadıkları kabul edilmektedir. Gerçekten de, Hobbes modern politikanın temel kavram ve problemlerinin kurucusudur. Descartes ise modern düşünüş tarzının ve metodunun başlıca kurucularındandır.

Gerek Descartes'in, gerekse Hobbes'un din ile ilgili düşünsel ve politik meselelerin had safhaya ulaştığı bir ortamda düşüncelerini geliştirdiklerini belirtmek gerekir. İki düşünür de dinsel çatışmaların şiddetlendiği ve düşünürlerin Roma Katolik Kilisesi'ne bağlı yargı sistemi tarafından tehdit edildikleri bir atmosferde, devraldıkları ve devam etmekte olan düşünsel problemlere cevap verme çabasındadır. Bu çerçevede, tıpkı Galileo gibi Descartes da Platoncu geleneğin devam ettiricisi olarak skolastik Aristotelesçi bilimsel geleneğin eleştiricileri arasında yer alarak, modern 
bilimin gelişimine öncülük etti (Shapere, 1963: 572). Ancak, Gillespie (2008: 190) Descartes'in, sıklıkla, Aristotelesçiliğe ilk karşı çıkan düşünürlerden bir olduğu kabul edilmesine rağmen, bu görüşün yanlış olduğunu belirtir. Ona göre Aristotelesçilik eleştirisi on üçüncü yüzylldan itibaren başlamıştır. Ayrıca, Descartes, Aristoteles'in kimi görüşlerini benimsemiş olsa da, Nominalizmin Tanrı nosyonunu kabul eder. Bu nedenle de Tanrı'nın yeryüzünü zorunlu olduğundan değil, fakat arzu ettiği için yarattığını düşünür. Bu anlamda, Tanrı'nın akıl tarafından idare edilmekte olduğuna dair skolastik görüsşe karşı çıkar.

Platoncu felsefenin genel ilkesine uyarak, Descartes da insani varoluşun iki farklı cismin birleşimi olduğuna inanır. Elbette, hem hayvanlar, hem de insanlar maddi bir varoluşa sahiptir. Ancak, Descartes, Hobbes'tan farkl1 olarak, insanın sadece mekanik bir varoluşa indirgenemeyeceğini düşünür. İnsan, aynı zamanda, ruhsal nitelikleri barındıran ahlaki bir varlıktır (Stent, 2002: 142). Bu anlamda, insan, devasa mekanik bir işleyişin sıradan bir parças1 değildir. Bu sayede Descartes (1993 [1641]) yeni bir bilimsel yaklaşım geliştirmek suretiyle insanın doğaya hükmetmesini temin etmeye çalışır. İnsan, mekanik biçimde işleyen dış dünyadan farklı bir biçimde, düşünsel etkinlikte bulunabildiği için, doğaya egemen olabilir. İnsanın dış dünyayı işleyebilmesinin olană̆ olmaması koşulu ile gerçekleşebilir.

Descartes, insani düşünme etkinliğine başat bir rol vererek, insanın dış dünya ile ilişkisini yeni bir boyuta taşır. İnsan, evrende yer alan diğer nesneler ile birlikte aynı harmoninin bir parçası olmaktan çıkarak, onları işleyen ve biçimlendiren bir rol kazanır. Bu bakış açısı onun epistemolojisine de yansır. Gillespie (2008: 197), Descartes'in, insanın bildiği şeylerin, sadece, insan tarafindan algılanmış oldukları için bilinmekte olduklarını düşündüğüne dikkat çeker. İnsan nesneleri algılayarak beyne ilettir. Bu ise insan iradesinin bir seçimi olarak gerçekleşir. Daha sonra Bergson (1960 [1889]) tarafindan etraflıca incelenecek olan bu görüss, alg1 teorisinin biçimlenmesi için gerekli düşünsel zeminin oluşmasını sağlayacaktır. Giderek, bilginin, insandan bağımsız bir biçimde var olduğu inanc1 terk edilecektir. Bunun yerine, bilgi insanın algılayarak biçimlendirdiği şeylerle sınırlı olan bir şey olarak anlaşılacaktır. Aynı zamanda, bilginin bir keşfin sonucu olmaktan ziyade, bir çeşit yaratım etkinliği ile oluştuğu düşünülmeye başlanacaktır. İnsanın düşünsel etkinliğine, mekanik biçimde işleyen doğay1 ve bilgiyi işleyen bir nitelik atfedilmesi, modernliği ortaya çıkaran tüm dinamiklerin etkin hale gelmelerini sağlar. Kişi sabit bir akılsal ve mantıksal etkinliğe uyum sağlamak zorunluluğundan azade oldukça, öznenin ve öznelliğin yaşamın biçimlenişindeki etkisi giderek artar.

Hobbes (1991 [1651]), "Leviathan" adlı eserinde açıkça görülebileceği üzere, tıpkı Descartes gibi, insanı doğa üzerinde egemen kılacak bir düşünce 
sistemi geliştirme çabasındadır. Avrupa'daki düşünce iklimi, on yedinci yüzyılda, insanı bir fail kılma eğilimindedir. İnsanın evrenin işleyişindeki rolüne dair düşüncelerde büyük bir dönüşüm gözlemlenir. Hümanist gelenek antik felsefeye, giderek daha fazla önem atfederek, insani etkinliğin önemine dikkat çekerken, Tanrı'nın mutlak iradesinin her şeyin belirleyicisi olduğu iddiasındaki deterministler dahi, Tanrı ile insan arasına büyük bir vadi açarak, insanın serbest biçimde davranabileceği bir sahanın oluşmasını sağlar. Bu anlamda değişik yollardan aynı neticeleri doğuran, iki farklı düşünce akımı ile karşı karşıya kalırız. Dolayısıyla, Hobbes, her ne kadar determinist bir yaklaşıma sahip olsa da, Descartes ile paralel neticeler doğuracak bir yaklaşıma sahiptir. Descartes'ten farklı olarak, insanın doğadaki diğer varlıklardan farklı bir konuma sahip olmadığına inanır (Gillespie, 2008: 222). Aristotelesçi akılcılı̆̆1 devam ettirerek, insan ile diğer varlıklar arasında bir ayrım yapılamayacağı savını öne süren Hobbes, esas itibariyle diğer bütün varlıkların evrendeki hareket dinamiklerini çözümleyerek, insan davranışlarının nasıl kontrol altına alınabileceğine odaklanır. Tam da bu noktada, Hobbes ile Descartes arasındaki farklılık belirgin biçimde ortaya çıkar. Nominalizmin etkisi ile kendi fizik teorisini geliştirmiş olan Hobbes, her şeyin değişim halinde olduğunu kabul eder. Bu bakış, evrenin Tanrı tarafindan en mükemmel bir biçimde yaratıldığ inancına dayanan klasik öğretiden kopuşun ifadesidir. Ancak, Hobbes değişimin varlığını kabul ederken, bunların çok sayıda birbirlerinden farklı değişimler oldukları düşüncesine karșı çıkar. Her ne kadar her șey değișim halinde olsa da, tüm değişimler merkezi bir değişimin neticesi olarak gerçekleştiğinden, birbirlerinden farklı yollara yönelmezler (Gillespie, 2008: 228).

Burtt (1925: 128-129) 'The Metaphysical Foundations of Modern Science' (Modern Bilimin Metafizik Temelleri) adlı eserinde, Hobbes'un, bireysel şeyleri gerçek varlıklar olarak kabul eden ortaçağın son dönemlerindeki nominalist eğilimler ile aynı çizgide yer aldığına dikkat çekerek, onun düşüncelerinin natüralizm, psikoloji, politika bilimi ve çağdaşları üzerindeki derin etkisini vurgular. Hobbes'un mekanik rasyonalizmi, her şeyin birbirleri ile uyum halinde hareket ettiği yeni bir evren kurgusuna ön ayak olur. Bu sayede doğa bilimlerinin her şeyin önüne geçmesini sağlar. Bu sayede, Hobbes ile birlikte, modernliğin temel yap1 taşlarından olan 'doğa bilimlerinin önceliği' tesis edilmiş olur. Hobbes, doğa bilimlerine öncelik vermek suretiyle, insanlar arasındaki farkl1liklardan kaynaklanan çatışmaları ortadan kaldırmayı amaçlar. Fransız devrimi ile politik arenanın ön kabullerinden biri haline gelecek eşitlikçi düşüncelere ilham vermesinin sebebi de, her şeyi tek bir merkezi hareketin sonucu olarak gören fizik anlayışıdır. $\mathrm{Bu}$ çerçevede, Sullivan (2004), Hobbes'un eşitlikçiliğinin liberal cumhuriyetçiliğe ilham vererek, insani var oluşun 
modern formuna öncülük ettiğini belirtir. Gerçekten de, her şeyin doğa yasalarına tabi olduğu ve eşitlendiği bir evren anlayışında, 'doğası gereği yöneten' ile 'doğası gereği yönetilen' ayrımının yapılabilmesine olanak kalmaz. Bu sayede insani etkinliğe, evrensel işleyiş içerisinde, yeni bir alan açılmış olur. ${ }^{10}$

\section{Sonuç: Algı Teorisi, Öznellik ve Hümanizm}

Tanrı nosyonuna dair tartışmalar, insanın dünyayı algılayışını köklü bir biçimde dönüştürmüștür. Tanrı ile insan ve dünya arasındaki ilișkinin nasıl olduğuna dair tüm tartışmalar insani etkinliğin yapısını etkilemiştir. $\mathrm{Bu}$ sayede insani etkinliğe verilen önem giderek artmıștır. Bunun doğal bir neticesi olarak, bilgi aranan, keşfedilen ve elde edilen bir şey olmaktan çıkar. Bilginin insanın dışında bir konuma sahip olduğu fikri, giderek geçerliliğini yitirir. İnsanın, dış dünyada mevcut bulunan pek çok şeyden sadece bir kısmını algılıyor olduğuna dikkat çekilerek, algılanan bu şeylere odaklanılır. Bergson (1944 [1907]) 'Creative Evolution' (Yaratıc1 Evrim) adlı eserinde Darvinci makinist evrim teorisine karşı çıkarken, insanın dış dünyayı algılarken, algıladığı nesneleri ve dünyayı sürekli yeniden inşa eden yaratıc1 bir etkinlikte bulunduğunu iddia eder. Bu sayede modern psikolojideki alg1 teorilerine de öncülük etmiş olur. Bu görüş, insanın öznelliğine vurgu yapan, nominalizmden etkilenen ve hümanizmin babası sayılan Petrarch'ın görüşlerinin en gelişmiş halidir. Parçaların birbiriyle uyumlu bir harmoni içinde olduğu Evren nosyonundan vaz geçilerek, her parçanın kendi biricikliğinde anlam kazandığı, bağlantısız parçacıklardan oluşan bir Evren nosyonuna geçiş, rölativist dünya görüşünün egemen hale gelmesini sağlarken, öznelliğin önemini giderek arttırmıştır. Evrendeki diğer parçalardan ayrı bir varlığa sahip olduğuna inanılan insanın, dış dünyayı

${ }^{10}$ Gerçekten de, gerek modern bilimin gerekse teolojinin esas problemi, insan fiillerinin evrenin işleyişinde nasıl bir biçimde konumlandırılacağıdır. Bu çerçevede, Turhan (1996) Abu al-Hassan Muhammed ibn Yusuf al-Amiri'nin “İkazu'l-Beșer mine'l-cebri ve'lkader" adlı eserini incelediği eserinde insan fiillerini kelam ve felsefe açısından değerlendirerek, meseleyi tarihsel sürecinde ele alır. Ona göre, Amiri, insana mutlak ilahi kudret karşısında hiçbir inisiyatif alanı bırakmayan Cebri görüş ile insanın ahlaki özgürlük tanımak adına ilahi kudreti sınırlandıran Kaderi ve Mutezili görüşlerini, aşırılıklarından arındırılarak, sentezlemeye çalışır. Bu manada, Amiri insan fiillerini felsefi olarak inceleyerek bir senteze ulașmıştır. Amiri'nin varmış olduğu neticeye göre "insan yaratılıștan akıllı nefs ve tabii kuvvetlerle donatılmıștır. Yaratma takdir etmedir. Âlemde olup biten her șey nefsani ve tabii kuvvetlerin etkileșimiyle külli bir sebep sonuç ilișsisi içinde cereyan etmektedir. Fiil yahut infial dediğimiz şeyler etkin ve edilgin kuvvetler arasındaki ilişkiden ibarettir. Her kuvvet kendisinden daha az olan kuvvete tesir eder. Akıl ve tabiat kuvvetlerine sahip bir varlık olarak insan, kendisinin üstündeki kuvvetlerden etkilenir, altındaki kuvvetleri etkiler. Bu itibarla o gücü oranında fiil seçme ve yapma hürriyetine sahiptir. Bir tabiat varllğı olarak insan tabiatın zaruretine bağll olduğu halde, aynı zamanda bir akıl varlı̆̆ı olarak tamamen hür ve bağımsızdır" (1996: 123). 
nasıl bir biçimde algıladığı modern bilimin ve felsefenin başlıca problemi haline gelmiştir. Böylece, diş dünyadaki nesnelerin gerçekliklerinin değil, fakat imajlarının insan bilimlerinin temel problemi olmasını sağlayan süreç, nominalist Tanrı kavrayışının egemen hale gelmeye başladığ1 on dördüncü yüzyıldan on dokuzuncu yüzyıla geçen zamanda tamamlanmıştır. Tanrının her şeyi, en baştan, bambaşka bir mantık ile yaratabileceğine dair inancın pekiştiği bir süreçte, determinizm ile özgür iradecilik, garip bir biçimde, birbirinin gelişmesini sağlayacak bir tarzda ilerlemiştir. Günümüzde yaygın bir biçimde tartışılan ve kabul edilen düşüncelerin ana kaynağı da on dördüncü yüzyıldan itibaren şiddetlenen teolojik tartışmalara çözüm arayışlarının bir neticesi biçiminde oluşmuştur.

Benzer bir biçimde Bergson'un düşüncelerinden etkilenen Alfred North Whitehead da modern psikoloji, eğitim bilimleri, iletişim bilimleri ve alg1 teorilerini derinden etkileyen "actual entity" (fiili varl1k) kavramın1, yukarıda açıkladığımız sürecin bir neticesi olarak ortaya atmıştır. Bu kavram, tıpkı Bergson'un 'élan vital' kavramı gibi, insani varoluşun bilimsel çalışmalarda merkezi önem arz etmeye başlaması ile oluşan yeni hümanist sürecin doğal bir neticesidir. Bergson (1944 [1907]), güncel insanlık durumunun varlığa geçmesine olanak sağlayan temel özelliğin ne olduğuna dair antropolojik bir sorudan hareket ile 'Creative Evolution' adli eserini yazd1. İnsani etkinliğin kendiliğinden yaratıcı bir etkinlik olduğu ve herhangi bir belirleyiciye tabi olmadan etkinliğini gerçekleştirdiğine dair inanç, on dokuzuncu yüzyılın ikinci yarısındaki entelektüel çalışmaların ana eksenidir. Her ne kadar Birinci Dünya Savaşı'ndan sonra insani etkinliğin özü itibari ile iyi olduğuna dair inanç sarsılmış olsa da, yirminci yüzyılın ilk yarısında da hümanist düşünceler etkinliğini korudu. Bu çerçevede, Whitehead da (1929) 'Processand Reality' adlı eserinde benzer doğrultuda görüşler ileri sürer.

Hümanizm, insani etkinliğin en değerli varoluş tarzı olduğu inancına dayanır. Ayrıca, hümanizm insani etkinliği sınırlandıran her türlü faktörün gerek politik, gerekse ekonomik sahadan temizlenmesini arzular. Nominalizmin on dördüncü yüzyılın başından itibaren başlattığı karşı çıkış, kendisine yönelik eleştiriler ile eşgüdümlü bir düşünsel etkileşim yaratarak, insani etkinliğin faaliyet sahasının, kültürel ve politik açıdan, genişlemesini temin etmiştir. Bu süreçte özgür iradeye inananlar ile deterministler arasında yoğun tartışmalar yaşanmıştır. Determinizm, sıklıkla, yapısalcılığın (structuralism) çeşitli formlarında su yüzüne çıkarken, özgür iradecilik insani algılamay1 ve algılanan nesnelerin insan alg1sı tarafından biçimlendirilen imajlarını başlica problem haline getiren alg1 teorilerini derinden etkilemiştir. Böylece insani etkinlik, kendisi dışındaki herhangi bir belirleyiciden bağımsız bir biçimde gerçekleşebilen bir olgu olarak değerlendirilmeye başlar. $\mathrm{Bu}$ durumun politik neticesi, insanlar arasındaki 
iletişimin, uzlaşmanın ve eşgüdümün başlıca referans kaynağ1 olması gerektiğini ileri süren teorilerin yaygın kabul görmesidir. Habermas'in (1984 [1981], 1987 [1981]) 'iletişimsel Eylem Teorisi'nde (Theorie des kommunikativen Handelns [The Theory of Communicative Action]) açık bir biçimde gözlemlenebileceği üzere, akıl nosyonunu 'nesnelci' yahut 'araçsal' terimlerden azade bir biçimde, özgür iletişimsel etkinliğe dayalı bir tarzda yeniden kurgulamaya yönelik girişimler, insani etkinliğin merkeze yerleştirilerek dünyayı anlama ve açıklama girişimlerinin devamıdır. İnsani etkinliğe merkezi bir önem verilmesi ve neticelerinin gerek dünya gerekse insanlık açısından olumlu olacağ 1 inancı liberalizm tarafindan da paylaşılır. Kısacası, insanın gerek tek başına, gerekse birlikte gerçekleştirdiği etkinliklere engel olabilecek tüm elementlerin toplumsal yaşamın dişına itilmesine yönelik eğilimler, son iki yüzyıllık süreçte giderek daha fazla kabul görmektedir. İletişim bilimleri ve alg1 teorileri ile birlikte sosyal bilimlerin, nesnenin gerçekte ne olduğundan ziyade nasıl algılandığına odaklanması, bahsetmiş olduğumuz sürecin doğal bir neticesidir.

\section{Kaynakça}

AQUINAS, Thomas. (2007) [1271-72], Commentary on Aristotle's Politics, translated by Richard J. Regan, Indianapolis \& Cambridge: Hackett Publishing Company.

ARSLAN, Ahmet. (2007), İlk Çă̆ Felsefe Tarihi 3: Aristoteles, İstanbul: İstanbul Bilgi Üniversitesi Yayınları.

BASINGER, David. (1983), "Why Petition an Omnipotent, Omniscient, Wholly Good God?", Religious Studies, Cilt. 19, No. 1, ss. 25-41.

BAYRAM, A. Kemal. (2009), "Modernlik ve Sosyal Bilimler: Bilgi, İktidar, Etik ve Toplum", Afyon Kocatepe Üniversitesi Sosyal Bilimler Dergisi, Cilt: XI, Say1 1, ss. 1-26.

BERGSON, Henri. (1944) [1907], Creative Evolution, translated by Arthur Mitchell, New York: The Modern Library.

BERGSON, Henri. (1960) [1889], Time and Free Will: An Essay on the Immediate Data of Consciousness, translated by F. L Pogson, New York: Harper \& Brothers.

BOURKE, John. (1947), "Frederickthe Great as Music-Loverand Musician", Music \& Letters, Cilt. 28, No. 1, ss. 63-77.

BURTT, E. A. (1925), The Metaphysical Foundations of Modern Science, New York: Harcourt, Brace \& Company.

DESCARTES, Rene. (1993) [1641], Meditations on First Philosophy, translated by Donald A. Cress, Indianapolis: Hackett Publications. 
ERASMUS, Desiderius \& LUTHER, Martin. (1985) [1524-25], Discourse on Free Will, edited \& translated by Ernst F. Winter, London: Continuum Publishing.

FREEDMAN, Joseph. S. (1993), "Aristotle and the Content of Philosophy Instruction at Central European Schools and Universities during the Reformation Era (1500-1650)", Proceedings of the American Philosophical Society, Cilt. 137, No. 2, ss. 213-253.

GARLICK, Fiona. (1997), "Dancesto Evoke the King: The Majestic Genre Chez Louis XIV.", Dance Research: The Journal of the Society for Dance Research, Cilt. 15, No. 2, Papers from the Dance to Honour Kings Conference, ss. 10-34.

GILLESPIE, Michael Allen. (2008), The Theological Origins of Modernity, Chicago: The University of Chicago Press.

GLAT, Mark. (1981), "John Locke's Historical Sense", The Review of Politics, Cilt. 43, No. 1, ss. 3-21.

HABERMAS, Jürgen. (1984) [1981], Theory of Communicative Action Volume One: Reason and the Rationalization of Society, translated by Thomas A. McCarthy, Boston \& Mass.: Beacon Press.

HABERMAS, Jürgen. (1987) [1981], Theory of Communicative Action Volume Two: Live-world and System: A Critique of Functionalist Reason, translated by Thomas A. McCarthy, Boston \& Mass.: Beacon Press.

HEDLEY, Douglas. (1996), "Pantheism, Trinitarian Theism and the Idea of Unity: Reflections on the Christian Concept of God", Religious Studies, Cilt. 32, No. 1, ss. 61-77.

HOBBES, Thomas. (1991) [1651], Leviathan, edited by Richard Tuck, Cambridge: Cambridge University Press.

ISHERWOOD, Robert. M. (1969), "The Centralization of Music in the Reign of Louis XIV.", French Historical Studies, Cilt. 6, No. 2, ss. 156-171.

JARROTT, C. A. L. (1970), "Erasmus' Biblical Humanism", Studies in the Renaissance, Cilt. 17, ss. 119-152.

JEFFREY, Pulver. (1912), "Music at the Court of Frederick the Great", The Musical Times, Cilt. 53, No. 835, ss. 599-601.

KENT, F. W. (2004), Lorenzo De' Medici and The Art of Magnificence, Baltimore \& London: The Johns Hopkins University Press.

KÖHLER, Walther. (1903), "Emperor Frederick II., The Hohenstaufe", The American Journal of Theology, Cilt. 7, No. 2, ss. 225-248.

LOCKE, John. (1988) [1689], Two Treatises of Civil Government, Cambridge \& New York: Cambridge University Press. 
NISBET, Robert. (1986), The Making of Modern Society, New York: New York University Press,

MEANS, Richard. L. (1966), "Protestantism and Economic Institutions: Auxiliary Theories to Weber's Protestant Ethic", Social Forces, Cilt. 44, No. 3, ss. 372-381.

O'BRIEN, Louis. (1931), "The Huguenot Policy of Louis XIV and Pope Innocent XI.", The Catholic Historical Review, Cilt. 17, No. 1, ss. 29-42.

O'MALLEY, John. W. (1974), "Erasmus and Luther, Continuity and Discontinuity as Key to Their Conflict", The Sixteenth Century Journal, Cilt. 5, No. 2, ss. 47-65.

PANOFSKY, Erwin. (1969), "Erasmus and the Visual Arts", Journal of the Warburg and Courtauld Institutes, Cilt. 32, ss. 200-227.

PEGIS, Anton. C. (1948), "Some Recent Interpretations of Ockham", Speculum, Cilt. 23, No. 3, ss. 452-463.

PETRARCH, Francesco. (1974) [1347-67], Petrarch's Bucolicum Carmen, translated by Thomas G. Bergin, New Haven: Yale University Press.

PETRARCH, Francesco. (1976), Petrarch's Lyric Poems: The Rimesparse and Other Lyrics, edited and translated by Robert M. Durling, Cambridge: Harvard University Press.

PINKARD, Terry. (2002), German Philosophy 1760-1860: The Legacy of Idealism, Cambridge \& New York: Cambridge University Press.

RESNICK, David. (1984), "Locke and the Rejection of the Ancient Constitution", Political Theory, Cilt. 12, No. 1, ss. 97-114.

SANDMAN, Susan Goertzel. (1977), "The Wind Band at Louis XIV's Court", Early Music, Cilt. 5, No. 1, ss. 27-37.

SHAPERE, Dudley. (1963), "Descartes and Plato", Journal of the History of Ideas, Cilt. 24, No. 4, ss. 572-576.

STENT, Gunther. S. (2002), "Paradoxes of Free Will", Transactions of the American Philosophical Society, New Series, Cilt. 92, No. 6, ss. i-iii, vix, xi-xii, 1-261, 263-273, 275-284.

STEPHENS, G. Ross. (1974), "State Centralization and the Erosion of Local Autonomy", The Journal of Politics, Cilt. 36, No. 1, ss. 44-76.

STOCK, Brian. (1995), "Reading, Writing, and the Self: Petrarch and His Forerunners", New Literary History, Cilt. 26, No. 4, ss. 717-730.

SULLIVAN, Vickie. B. (2004), Machiavelli, Hobbes, and the Formation of a Liberal Republicanism in England, Cambridge \& New York: Cambridge University Press. 
TOKTAŞ, Fatih. (2004), İslam Düşüncesinde Felsefe Eleştirileri, İstanbul: Klasik Yayınları.

TURHAN, Kasım. (1996), Bir Ahlak Problemi Olarak Kelam ve Felsefe Açısından İnsan Fiilleri, İstanbul: Marmara Üniversitesi İlahiyat Fakültesi Vakfi Yayınları.

WEBER, Max. (2008) [1908-20], Max Weber's Complete Writings on Academic and Political Vocations, edited by John Dreijmanis; translation by Gordon C. Wells, New York: Algora Publishing.

WHITE, Lynn. (1978), "Science and the Sense of Self: The Medieval Background of a Modern Confrontation", Daedalus, Cilt. 107, No. 2, Limits of Scientific Inquiry, ss. 47-59.

WHITEHEAD, Alfred North. (1927), Symbolism: Its Meaning and Effect (Barbour-Page Lectures, University of Virginia, 1927), New York: Fordham University Press.

WHITEHEAD, Alfred North. (1929), Process and Reality: An Essay in Cosmology (Gifford Lectures Delivered in the University of Edinburgh During the Session 1927-1928), New York: Free Press.

WILKINS, Ernest H. (1964), "On the Evolution of Petrarch's Letterto Posterity", Speculum, Cilt. 39, No. 2, ss. 304-308.

ZAK, Gur. (2010), Petrarch's Humanism and the Care of the Self, Cambridge: Cambridge University Press. 